\title{
Kimberlite emplacement and mantle sampling through time at A154N kimberlite volcano, Diavik Diamond Mine
}

\author{
Moss., S. ${ }^{1}$; Kobussen, A. ${ }^{2}$; Powell, W. ${ }^{2}$; Pollock, K. ${ }^{3}$; Cutts, J. ${ }^{4}$ \\ ${ }^{1}$ Terram Vero Consulting Inc., Vancouver, Canada, smoss@terramvero.com \\ ${ }^{2}$ Rio Tinto Exploration, Melbourne, Australia, alan.kobussen@riotinto.com,will.powell@ riotinto.com \\ ${ }^{3}$ Diavik Diamond Mines Inc., Yellowknife, Canada,kpollock@ riotinto.com \\ ${ }^{4}$ The University of British Columbia, Vancouver, Canada, jcutts@eos.ubc.ca
}

\section{Introduction}

The Diavik Diamond Mine in the NWT of Canada (Fig. $1 \mathrm{~A}, \mathrm{~B})$ has produced in excess of 100 million carats from 3 kimberlite pipes since mining commenced in 2002, and geology work to support mining has generated new insights into the nature of kimberlite pipes at Lac de Gras to depths $>700 \mathrm{~m}$ below surface. Here, we present new findings from deep ( $>400 \mathrm{~m}$ below surface) mining, sampling and drilling work on the A154N kimberlite volcano. The drilling and mining has revealed additional geological domains, and contact relationships apparent among the eight domains (Dueys, PK1-N, VRVK-1N, PK2-N, PK3-N, MRVK2-N, PK4-N, CK-N) allow for a sequential organization of emplacement events. Updated 3D internal geological models and pipe shapes for A154N are also presented which expand upon understandings of Lac de Gras kimberlite pipe morphology.

Representative populations of mantle minerals extracted from the various geological units corresponding to discrete kimberlite magmas at A154N are analyzed for major and trace elements, and provide insights into the nature of the mantle sampled through time in a single kimberlite volcano.

These findings require a revision of previous geological and emplacement models and provide a window into how the sub-continental lithospheric mantle (SCLM) below Diavik was sampled by kimberlite magmas through time.

\section{Updated A154N architecture}

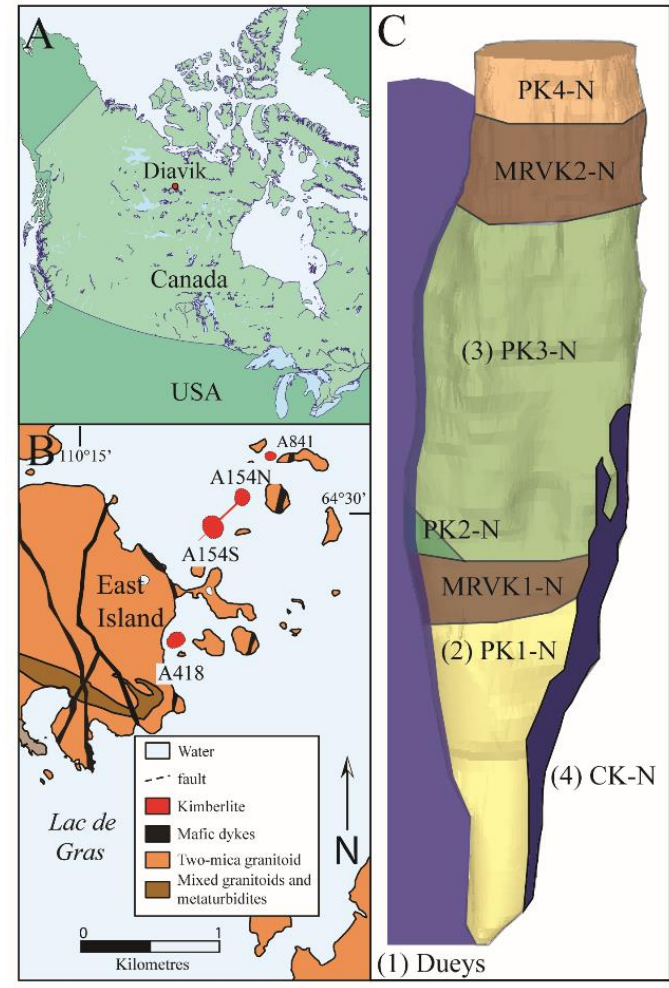

Figure 1: a) Location of Diavik within Northwest Territories of Canada; b) the kimberlite bodies at Diavik, superimposed on geological mapping of Lac de Gras area from Stubley (1998); c) schematic showing updated geological model of A154N comprising a precursor dyke (Dueys), and seven different geological domains. The relative timing of five temporally-discrete contributions of magma within or adjacent to A154N are shown with numbers 1 to 4 . Modified from Moss et al. (2009).

Contact relationships apparent among the geological domains allow for a sequential organization of emplacement events, and identify as many as four temporally-discrete contributions of kimberlite magma within or surrounding A154N: (1) Dueys; (2) PK1-N; (3) PK3-N; (4) CK-N. Pipe excavation and deposit emplacements within A154N were preceded by emplacement of coherent kimberlite within a pre-existing structure known as "Dueys" striking at $030^{\circ}$ (Dueys; Fig. 1C). The updated internal geology features two volcanic packages, each comprising massive, mud-poor, poorly-sorted pyroclastic deposits with minimal country rock clasts overlain by mud-rich, moderately- to well-sorted volcaniclastic deposits (i.e. PK1-N/MRVK1-N and PK3-N/MRVK2-N; Fig. 1C). Late stage coherent 
kimberlite cross-cuts the deeper pyroclastic and volcaniclastic deposits (CK-N; Fig. 1). This layer-cake architecture is interpreted to represent two successive cycles of explosive eruption from within A154N followed by active and passive sedimentation from a presumed crater-rim, and the whole package of deposits are both preceded (i.e. Dueys) and followed (i.e. CK-N) by intrusions of coherent kimberlite. The top of A154N is infilled by an externally-sourced graded deposit of pyroclastic kimberlite (PK4N) captured by and preserved within a maar crater as described by Moss et al. (2008; 2009).

\section{Mineral chemistry}

To support an investigation of how the SCLM was sampled through time at a single kimberlite volcano, a statistically significant and representative subset of garnet and clinopyroxene grains were extracted from each domain in A154N for mineral chemistry analysis. Major and trace element analyses were carried out on $>600$ garnet xenocrysts, using electron microprobe and laser ablation inductively coupled plasma-mass spectrometry, respectively. Garnet grains were classified based on their compositions according to Grütter et al. (2004). We utilized the empirical Ni-in-garnet thermometer as described by Ryan et al. (1996) to calculate equilibration temperatures for peridotitic garnets. Equilibration pressures for garnets were estimated by applying a "kinked" geotherm comprising $38 \mathrm{~mW} / \mathrm{km}$ and $40 \mathrm{~mW} / \mathrm{km}$ geotherms from Hasterok and Chapman (2011) to grains with calculated temperatures above and below $950^{\circ} \mathrm{C}$, respectively. Chrome diopside compositions were used to estimate pressure and temperature conditions of formation using the thermobarometric methods of Nimis and Taylor (2000). Calculated garnet and chrome diopside pressures were translated to equivalent depths using an assumed density profile comprising $80 \%$ lithospheric mantle $\left(\rho=3.30 \mathrm{~g} / \mathrm{cm}^{3}\right)$ and $20 \%$ lithospheric crust $(\rho=2.65$ $\left.\mathrm{g} / \mathrm{cm}^{3}\right)$.

Calculated depths from cpx grains indicate that garnet lherzolite from the SCLM sampled by the kimberlite magmas feeding A154N ranged from depths of $100 \mathrm{~km}$ to $200 \mathrm{~km}$ depth. More than $75 \%$ of the grains among all domains are sourced from the 110-160 $\mathrm{km}$ depth range, and a relatively even distribution of the remaining grains are sourced from $>160 \mathrm{~km}$. Calculated depths indicate that kimberlite magmas emplaced in A154N sampled progressively deeper mantle through time (Fig. 2).

Garnets from two samples analyzed for minor elements and REE to date also show $>75 \%$ of the grains are sourced from $110-160 \mathrm{~km}$, and a similar increase in sampling depth with time (Fig. 3). Lherzolitic and harzburgitic garnets are

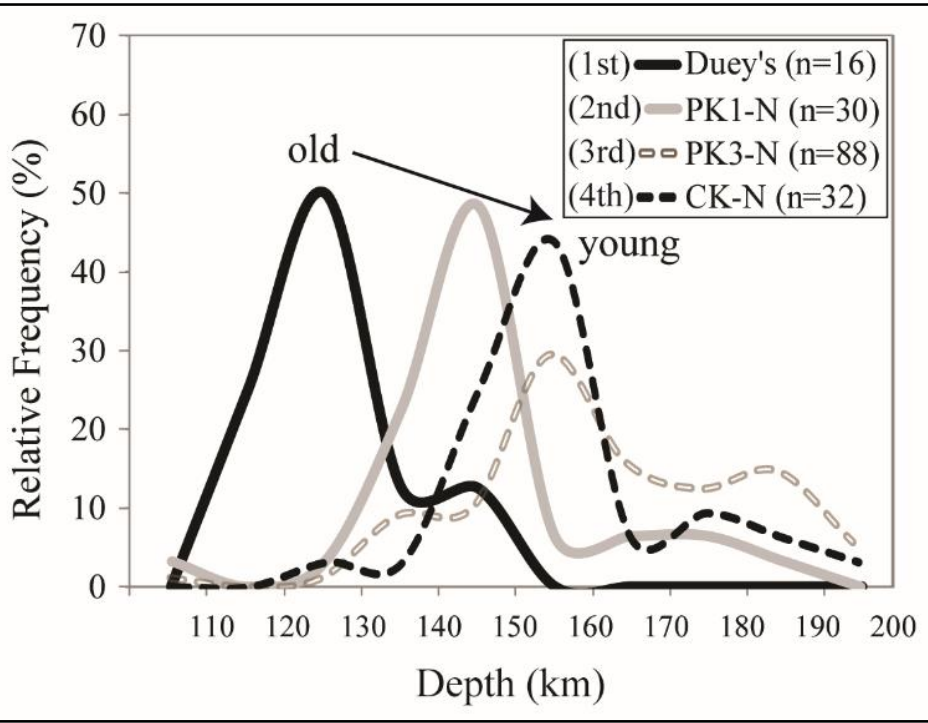

Figure 2: Relative abundances of calculated source depths of clinopyroxene among magmatic and pyroclastic deposits at A154N. The known relative timing indicates magmas emplaced at surface entrained successively deeper mantle through time. present in similar abundances from 130 to $160 \mathrm{~km}$ in PK1-N. The earlier PK1-N mantle sample shows a distinctively higher relative proportion of harzburgite than that of the subsequently emplaced PK3-N which fills the majority of A154N. These results also collectively show a restricted depth range from which the majority of mantle peridotite was sampled for two key pipe-filling deposits.

The $\mathrm{Zr}, \mathrm{TiO} 2, \mathrm{Y}$ and $\mathrm{Ga}$ compositions of peridotitic garnets are evaluated over the range of estimated depths to test models of the SCLM underlying the central Slave terrane. Preliminary results show an increase in $\mathrm{Y}, \mathrm{Zr}$ and $\mathrm{TiO} 2$ corresponding to depths of approximately $160 \mathrm{~km}$. 


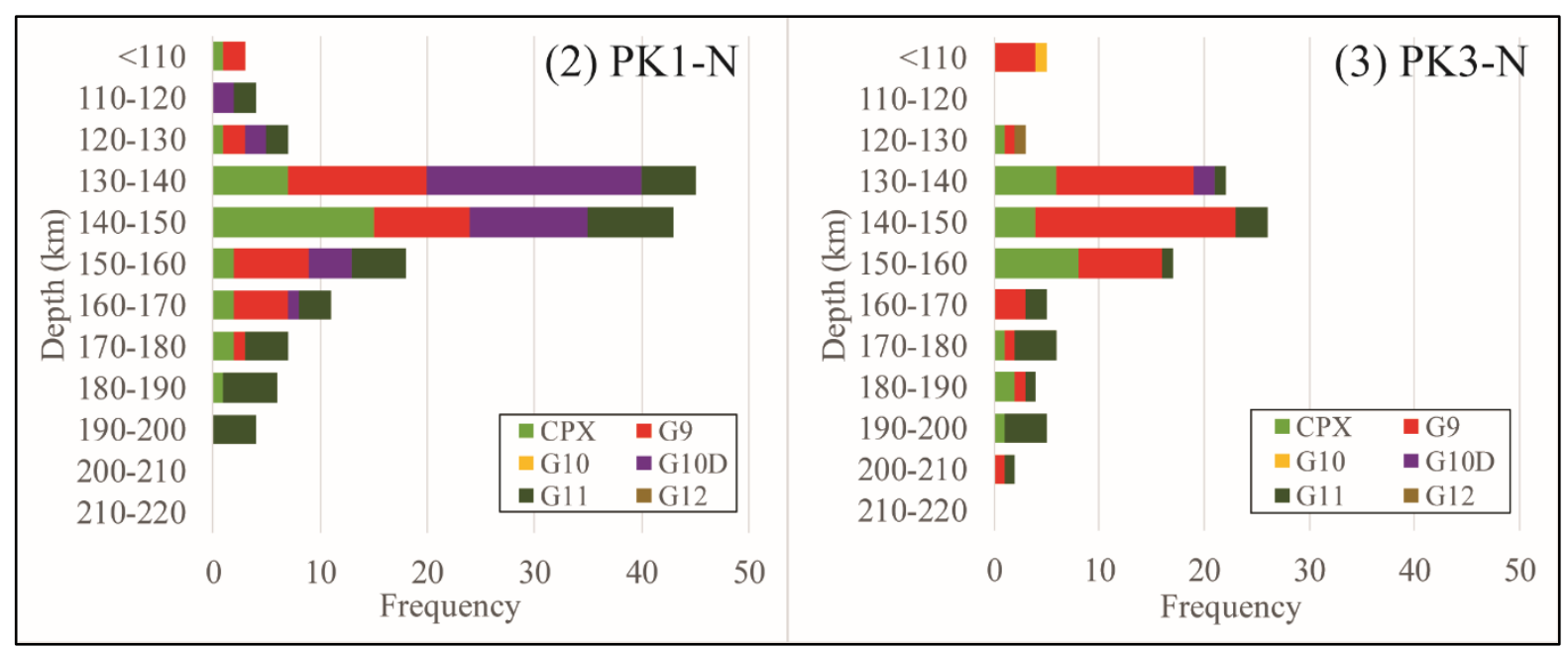

Figure 3: Calculated source depths for clinopyroxene and peridotitic garnets. Thermobarometry techniques described by Nimis and Taylor (2000) and Ryan et al. (1996) were applied to PK1-N and PK3-N, and converted to equivalent depths. Parentheses indicate relative timing of emplacement of kimberlite source magmas within A154N. Peridotitic garnets classified using Grutter et al. (2004): G9 = lherzolitic garnet; G10 = harzburgitic garnet; G10D = harzburgitic garnet consistent with inclusions in diamond; G11 = High-Ti peridotitic garnet; G12 = wehrlitic garnet.

Ramen spectroscopy techniques are used to calculate pressures of formation for inclusions in diamonds from select units, and results test the hypothesis that, in contrast to the garnet lherzolite sample, the diamonds in each kimberlite magma emplaced at A154N are sourced from a common depth horizon.

These findings both complement and contradict aspects of current models for mantle stratigraphy of the central Slave SCLM (e.g. Griffin, et al. 1999), and have potential implications upon the application of mantle mineral chemistry in exploring for and evaluating kimberlite bodies.

\section{References}

Griffin W, Doyle B, Ryan C, Pearson N, O'Reilly S, Davies R, Kivi K, Van Achterbergh E, Natapov L (1999) Layered mantle lithosphere in the Lac de Gras area, Slave craton: composition, structure and origin. Journal of Petrology 40(5):705-727

Grütter HS, Gurney JJ, Menzies AH, Winter F (2004) An updated classification scheme for mantlederived garnet, for use by diamond explorers. Lithos 77(1-4):841-857

doi:10.1016/j.lithos.2004.04.012

Hasterok D, Chapman D (2011) Heat production and geotherms for the continental lithosphere. Earth and Planetary Science Letters 307(1):59-70

Moss S, Russell JK, Andrews GDM (2008) Progressive infilling of a kimberlite pipe at Diavik,

Northwest Territories, Canada: Insights from volcanic facies architecture, textures, and granulometry.

Journal of Volcanology and Geothermal Research 174(1-3):103-116

doi:10.1016/j.jvolgeores.2007.12.020

Moss S, Russell JK, Brett RC, Andrews GDM (2009) Spatial and temporal evolution of kimberlite magma at A154N, Diavik, Northwest Territories, Canada. Lithos 112, Supplement 1(0):541-552 doi:10.1016/j.lithos.2009.03.025

Ryan CG, Griffin WL, Pearson NJ (1996) Garnet geotherms: Pressure-temperature data from Crpyrope garnet xenocrysts in volcanic rocks. Journal of Geophysical Research: Solid Earth 101(B3):5611-5625

Stubley MP (1998) Bedrock Geology of the East Island Area, Lac de Gras, unpublished internal report prepared for Diavik Diamond Mines Inc. 